\title{
Diversity of the \\ Zooplankton (Alpha and Beta) in the Lentic \\ Environment in the Miranda River Basin (MS, Brazil)
}

Silva, W.M. ${ }^{1}$, Zanata, L.H. ${ }^{1}$, Roche, K.F. ${ }^{2}$, Silva, T.H.P.N. ${ }^{3}$, So uza, J..$^{3}$, Severino, L.V. ${ }^{4}$, Dua rte, J .D. ${ }^{4}$, Orika ssa, T.N. ${ }^{4}$

'Universida de Federal de Mato Grosso do Sul - Campus Pantanal, Corumbá, MS, Brazil. 2Universida de Federal de Mato Grosso do Sul - FAENG, Campo Grande, MS, Brazil. ${ }^{3}$ Curso de Pós-Graduação em Tecnologias Ambienta is - FAENG, Campo Grande, MS, Brazil.

${ }^{4}$ Curso de Pós-Graduação em Biologia Animal - CCBS, Campo Grande, MS, Brazil. Corresponding autor: wmsilvax@ig.com.br

\section{Abstract}

The zooplankton is one the ma in components of the freshwater environments, and play fundamental services in a quatic system. The diversity of the zooplankton is central to ma inta in these services and inc rease resilience of the system. The a im of this present work was to obta in the values of alpha-diversity, ecologic al diversity and beta-diversity for zooplankton (Rotifera, Cladocera and Copepoda) in lentic environments with different origins, uses, preservation stages in the Miranda River Basin (MRB), Mato Grosso do Sul State (Brazil). The zooplankton was sampled with a graduated trap and filtering water using a net with $20 \mu \mathrm{m}$ of pore size. After counting, the organism it wasapplied the Whitta ker beta diversity coeffic ient and Shannon-wiener diversity index. The total ric hness for each zooplankton group was 62 for Rotifera, 32 for Copepod and 26 for Cladocera. The MRB has two hotspot with different origin and use, one a urban 
reservoir and another a water outcropping. Cladocera presents a more restricted distribution with highest diversity in the platea u and more homogenous population than Rotifera and Copepoda presented a similar pattem.

Keywords: zooplankton distribution, a qua tic ecology, freshwater dispersion, Pa ragua y River Ba sin.

\section{Introduction}

The zooplankton is one the main components of the freshwater environments, and play fundamental services in aqua tic system. These servic es include the nutrient cycling in water (VANNI, 2002) and the energy tranfer by food chain web (TUNDISI, MATSUMURA-TUNDISI, 2003; DIC KMAN et al. 2008). The diversity of the zooplankton is central to mainta in these servic es and increase resilience of the system (DOWING, LEIBO LD, 2010; AWIT, 2011).

Among the many ways to measure the biological diversity, the ric hness (a Ipha-diversity) a nd ecologic a I diversity (Shannon-Weiner index) are the most used (MATSUMURA-TUNDISI, 1997). Another diversity related to spatial a rea is the Beta-diversity that is the product of Gamma diversity (total species of some a rea) by alpha-diversity (the local number of species) (WITHAKER, 1972). Where, if the environment is composed by many sites with low beta-diversity mea ns there is high simila rity a mong them.

The environment changes promote by c lima te and by human a c tivities impact the freshwater system (PERKINS et al., 2015; WALSH et al. 2016) and the diversity dec reasing resulting in loss of biodiversity and diminishing the ecosystem services. In many freshwater systems surrounded by human activities, the biodiversity dec rease changing the ecological diversity too in general became the environment less heterogenic. According McKnight et al. (2007) the environmental homogenization promoting by huma $n$ activities implies in reduction of beta-diversity.

The aim of this present work was to obta in the values of alpha-diversity, ecologic al diversity and beta-diversity for zooplankton (Rotifera, Cladocera and Copepoda)

in lentic environments with different origins, uses, preservation stages in the Miranda River Basin (MRB), Mato Grosso do Sul Sta te (Brazil).

\section{Material and Methods}

The figure 1 show the Miranda River Basin location and the sample point distributions. It were sampled 24 lentic water bodies, including na tural and a rtific ial ones. In each lake were sampled water for chemical and physical analysis. The zooplankton was sampled with a graduated tra $p$ and filtering water using a net with 20 $\mu \mathrm{m}$ of pore size. The filtered sample was preserved using formaldehyde with $4 \%$ in a polyethylene flask. The identific ation and quantification of zooplankton were done using optical mic roscope and 
stereoscope mic roscope and specialized bibliography. It were apply the Whittaker beta diversity coefficient $(y / a)$, where $Y$ is the gamma diversity (all species in the river basin) and $a$ is the alpha diversity (all local species) and Shannon-wiener diversity index (- $\sum$ pi In pi) where pi is the rela tive density of each species at local. The median $(\tilde{x})$ wascalculated for each group.

\section{Results}

The total ric hness for ea ch zo opla nkton group was 62 for Rotifera, 32 for Copepod and 26 for Cladocera. The Rotifera has recorded in 23 sites, the Copepoda in 22 sites and the Cladocera in 15 sites.

The table 1 shows the values for ric hness, Sha nnon-Weiner Index and $\beta$-diversity for zooplankton groups in each sample point.

The results shows that Rotifera presented 12 sites above the median values for diversity index and 11 for Beta-diversity. Copepoda had the same values 12 sites for diversity index and 11 for Beta-diversity, but with one site less and Cladocera presented 8 and 7 respectively.

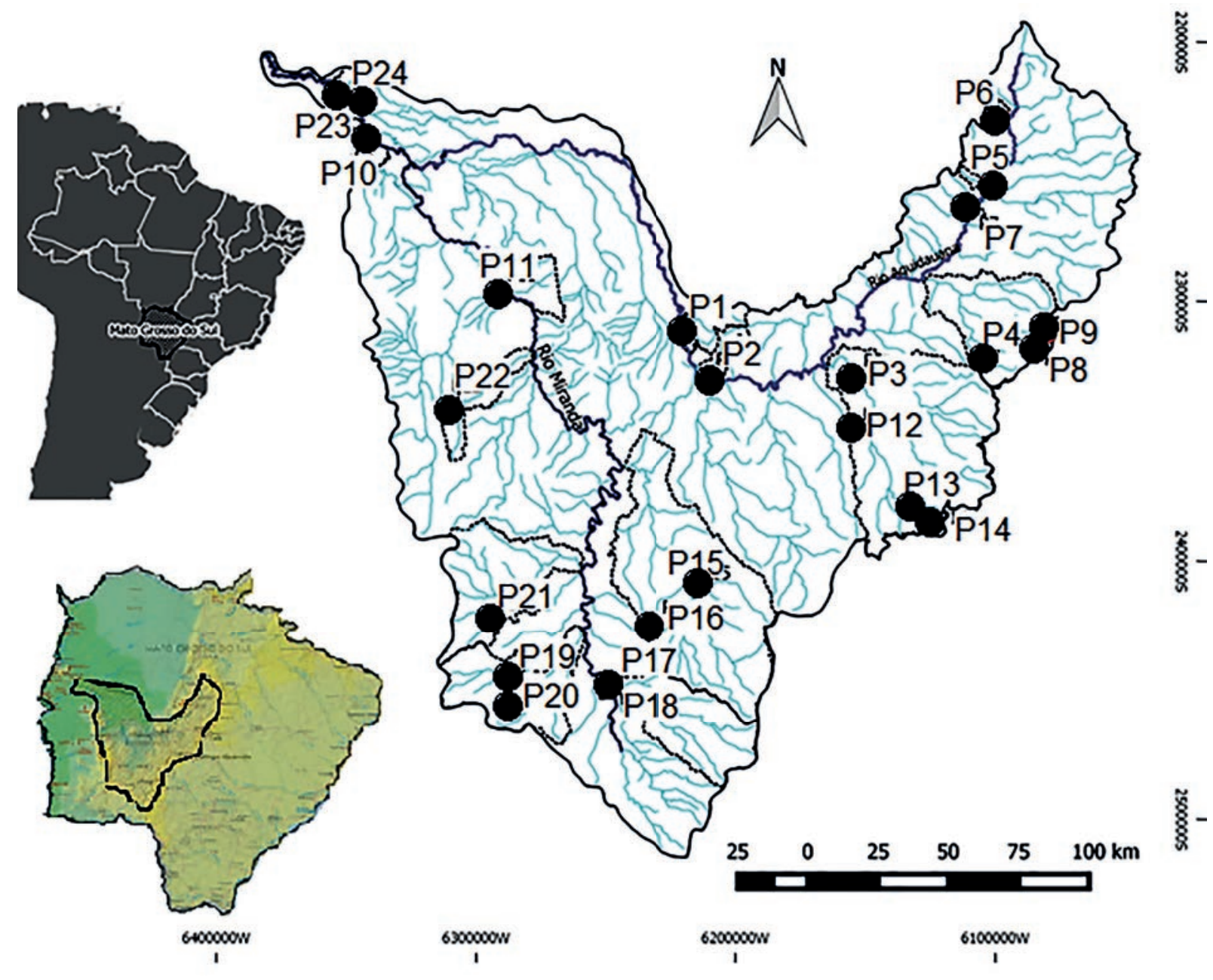

Figure 1 - Location of the Miranda River Basin in the Mato Grosso do Sul State and the samples points distribution. 
Table 1 - The values for richness, Shannon-Weiner index $(H)$ and Beta-diversity $(\beta)$ for Rotifera, Copepoda and Cladocera in the MRB sites and median $(\tilde{x})$.

\begin{tabular}{|c|c|c|c|c|c|c|c|c|c|c|c|}
\hline \multicolumn{4}{|c|}{ Rotifera } & \multicolumn{4}{|c|}{ Copepoda } & \multicolumn{4}{|c|}{ Cladocera } \\
\hline Sites & Richness & $\mathrm{H}$ & $\beta$ & Sites & Richness & $\mathrm{H}$ & $\beta$ & Sites & Richness & $\mathrm{H}$ & $\beta$ \\
\hline P1 & 14 & 2,4 & 4,4 & P1 & 3 & 0,9 & 10,7 & $\mathrm{P} 2$ & 16 & 1,7 & 1,6 \\
\hline P2 & 17 & 2,4 & 3,6 & P2 & 13 & 1,8 & 2,5 & P4 & 6 & 1,6 & 4,3 \\
\hline P3 & 5 & 1,3 & 12,6 & P3 & 4 & 0,6 & 8,0 & P6 & 1 & 0,0 & 26,0 \\
\hline P4 & 12 & 1,5 & 5,2 & P4 & 4 & 0,9 & 8,0 & P11 & 1 & 0,0 & 26,0 \\
\hline P5 & 10 & 1,6 & 6,2 & P5 & 3 & 0,2 & 10,7 & P12 & 5 & 1,3 & 5,2 \\
\hline P5 & 8 & 1,7 & 7,8 & P6 & 4 & 1,3 & 8,0 & P13 & 3 & 0,4 & 8,7 \\
\hline P6 & 14 & 2,5 & 4,4 & P7 & 1 & 0,0 & 32,0 & P14 & 6 & 0,6 & 4,3 \\
\hline P8 & 4 & 1,3 & 15,5 & P9 & 4 & 1,3 & 8,0 & P15 & 3 & 0,5 & 8,7 \\
\hline P9 & 2 & 0,5 & 31,0 & P10 & 1 & 0,0 & 32,0 & P16 & 1 & 0,0 & 26,0 \\
\hline P11 & 3 & 0,6 & 20,7 & P11 & 2 & 0,7 & 16,0 & P17 & 3 & 1,1 & 8,7 \\
\hline P12 & 5 & 1,3 & 12,4 & P13 & 4 & 1,4 & 8,0 & P19 & 5 & 1,3 & 5,2 \\
\hline P13 & 8 & 0,7 & 7,8 & P14 & 2 & 0,5 & 16,0 & P20 & 5 & 0,9 & 5,2 \\
\hline P14 & 9 & 1,4 & 6,9 & P15 & 11 & 1,7 & 2,9 & P21 & 5 & 0,5 & 5,2 \\
\hline P15 & 13 & 0,8 & 4,8 & P16 & 5 & 1,6 & 6,4 & P22 & 4 & 0,9 & 6,5 \\
\hline P16 & 8 & 1,4 & 7,8 & P17 & 3 & 1,1 & 10,7 & P23 & 3 & 0,2 & 8,7 \\
\hline P17 & 10 & 1,6 & 6,2 & P18 & 9 & 1,4 & 3,6 & & & & \\
\hline P18 & 12 & 2,0 & 5,2 & P19 & 3 & 1,1 & 10,7 & & & & \\
\hline P19 & 15 & 2,6 & 4,1 & P20 & 3 & 0,4 & 10,7 & & & & \\
\hline P20 & 6 & 0,4 & 10,3 & P21 & 6 & 0,9 & 5,3 & & & & \\
\hline P21 & 2 & 0,7 & 31,0 & P22 & 2 & 0,7 & 16,0 & & & & \\
\hline P22 & 4 & 1,3 & 15,5 & P23 & 8 & 1,0 & 4,0 & & & & \\
\hline P23 & 10 & 2,0 & 6,2 & P24 & 2 & 0,6 & 16,0 & & & & \\
\hline P24 & 14 & 1,8 & 4,4 & & & & & & & & \\
\hline$\tilde{x}$ & 9,0 & 1,4 & 6,9 & $\tilde{x}$ & 3,5 & 0,9 & 9,3 & $\tilde{x}$ & 4,0 & 0,6 & 6,5 \\
\hline
\end{tabular}

The figure $2 \mathrm{~A}-\mathrm{C}$ shows the loc ation in the MRB of the samples points with high and lowest diversity for the zooplankton group. There were few coincident pointsfor both higher and lower diversity. 
Diversity of the Zooplankton (Alpha and Beta)...
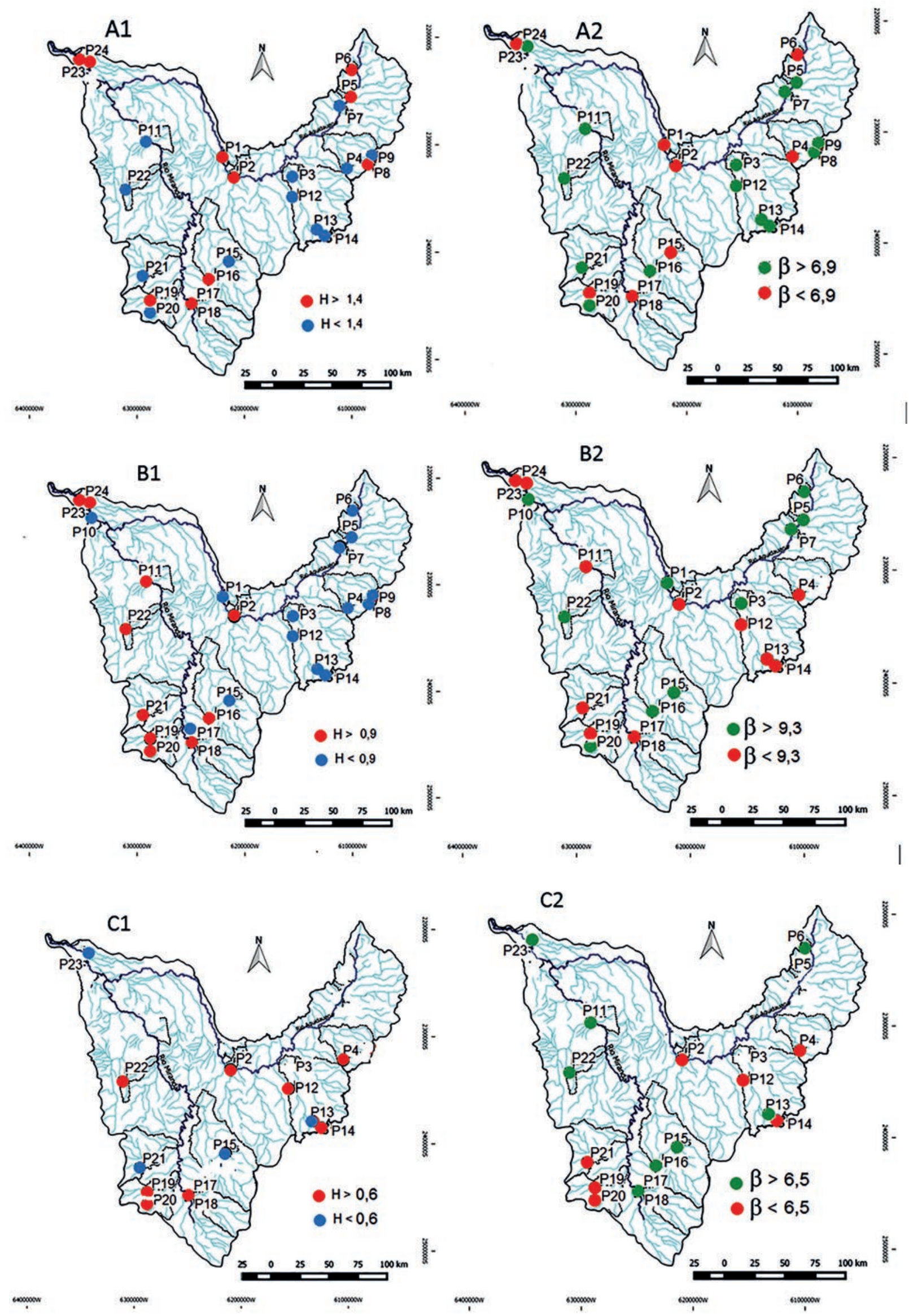

Figure 2 - Distribution of diversity index and beta-diversity for Rotifera $A 1$ and $A 2$; for Copepoda B1 and B2; for Cladocera C1 and C2. 


\section{Discussion}

The distribution of zooplankton has two components by local such as water chemistry and regional factors such as c limate variation (SHURIN et al. 2000). in the RMB the main regional factor is the altimetry degree with high in the east about 250 to $1200 \mathrm{~m}$ and low in the west, Pantanal floodpla in a bout 80 to $150 \mathrm{~m}$ (ALMEIDA et al. 2015).

Rotifera and Copepoda were the most frequent groupsand the Cladocera the less one. The high absence of Cladocera show the na rrow ecological when compared with the Rotifera and Copepoda as observed in other studies of distrib ution (PANARELLI et al. 2013; PINEL-ALOUL, MIMOUNI, 2013). Cladoceran was not retricted to a region but has presented minor frequency in floodpla in area, which is driven by high water fluctuation (ROSSA et al. 2001; PANARELLI et al. 2013; KARPOWICZ, 2016).

Diversity index highest values for Rotifera, Cladocera and Copepoda show some overlap, and point to the hotspot that support high diversity for all groups. Points 2 and 19 are the hotspot. The point 2 is an urban reservoir and 19 is a water outcropping in a cattle farm. These agree with the environmental heterogeneity promotes the diversity in zooplankton communities (COTIENIE, DE MEESTER, 2004; BARNEIT, BEISNER, 2007). Both Rotifera and Copepoda hasa hotspot too in the Pantanal a rea, points 23 and 24, and Cladocera not, with a greementof the hypothesis that this group are most susceptible to wa ter level va ria tion (ROSSA et a I. 2001; PANARELLI et al. 2013; KARPOWICZ, 2016).

Beta-Diversity used be high when the diversity index is low, but some incongruence can be found. The Cladoceran presented a high congruence between both diversities and Rotifera and Cladocera less congruence. Cladocera population is more homogenous (shares more species) in the water bodies, and Rotifera and Copepoda more heterogeneous. The Cladocera presents more restricted environmets and probably is more sensitive to environmental changes (SHURIN et al. 2010), once that population is more homogenous. Most of lakes show a poor combination for diversity had high beta-diversity and low a lpha-diversity (with low diversity index) that is expected (KO LEFF et al. 2003). The small lakes with low diversity index and high beta-diversity valuesare important repository cause has high density that facility the dispersion (DE BIE et al. 2008).

These results combining betadiversity and diversity index drives for two main statements, which works as a tool for environmental managers. The first, Cladocera community shows more sensitive to regional changes, such as plateau and floodplain areas that is in a greement with other distribution studies (SHURIN et al. 2000; NEVALAINEN et al. 2010, SWEETMAN, RÜHLAND 2010). The second, Rotifera and Copepoda communities is determinate by local process, such as pollution and eutrophic ation, these communities histo ric a lly is used for loc al 
water quality indicator (SLÁDEČEK, 1983, MATSUMURA-TUNDISI, 1999, SILVA, 2011, PERBIC HE-NEVES et a I., 2013).

Concluding, the MRB has two hotsp ot with different origin and use, one a urban reservoir and a nothera water outcropping. Cladocera presents a more restricted distribution with highest diversity in the

\section{References}

ALMEIDA, T.I.R., PENATTI, N.C., FERREIRA, L.G., ARANTES, A.E. and DO AMARAL, C.H., 2015. Principal component analysis applied to a time series of MODIS images: the spatio-temporal variability of the Pantanal wetland, Brazil. Wetlands ecology and management, vol. 23, no. 4, pp. 737-748.

AWITI, A., 2011. Biological diversity and resilience: lessons from the recovery of cichlid species in Lake Victoria. Ecology and Society, vol. 16, no. 1. URL: http://www.ecologyandsociety.org/vol16/iss1/art9/

BARNETT, A. and BEISNER, B.E., 2007. Zooplankton biodiversity and lake trophic state: explanations invoking resource abundance and distribution. Ecology, vol. 88, no. 7, pp. 1675-1686.

COTTENIE, K. and DE MEeSTER, L., 2004. Metacommunity structure: synergy of biotic interactions as selective agents and dispersal as fuel. Ecology, vol. 85, no. 1, pp. 114-119.

DE BIE, T., DECLERCK, S., MARTENS, K., DE MEESTER, L. and BRENDONCK, L., 2008. A comparative analysis of cladoceran communities from different water body types: patterns in community composition and diversity. Hydrobiologia, vol. 597, no. 1, pp. 19-27.

DICKMAN, E.M., NEWELL, J.M., GONZÁLEZ, M.J. and VANNI, M.J., 2008, Light, nutrients, and foodchain length constrain planktonic energy transfer efficiency across multiple trophic levels. Proc Nat/ Acad Sci, vol. 105, no. 47, pp. 18408-18412. http:// doi.org/10.1073/pnas.0805566105

DOWNING, A.L. and LEIBOLD, M.A., 2010. Species richness facilitates ecosystem resilience in aquatic food webs. Freshwater Biology, vol. 55, no. 10, pp. 2123-2137. plateau and more homogenous population than Rotifera and Copepoda presented a similar pattern.

\section{Acknowledgement}

We a re thankful to FUNDECT/SUC ITEC/ SEMAC No 09/2012 - BIOTA-MS for their financial support and sc holarship a warded.

KARPOWICZ, M., 2016. Biodiversity of microcrustaceans (Cladocera, Copepoda) in a lowland river ecosystem. Journal of Limnology, vol. 76, no. 1.

KOLEFF, P., GASTON, K.J. and LENNON, J.J., 2003. Measuring beta diversity for presence-absence data. Journal of Animal Ecology, vol. 72, no. 3, pp. 367-382.

MATSUMURA-TUNDISI, T., 1999. Diversidade de zooplâncton em represas do Brasil. In: HENRY, R. Ecologia de reservatórios: estrutura, função e aspectos sociais. Botucatu: Fapesp, Fundibio, cap. 2, p. 39-54.

MCKNIGHT, M.W., WHITE, P.S., MCDONALD, R.I., LAMOREUX, J.F., SECHREST, W., RIDGELY, R.S. and STUART, S.N., 2007. Putting beta-diversity on the map: broad-scale congruence and coincidence in the extremes. PLoS biology, vol. 5, no. 10, p. e272. NEVALAINEN, L., LUOTO, T.P., KULTTI, S. and SARMAJAKORJONEN, K., 2013. Spatio-temporal distribution of sedimentary Cladocera (Crustacea: Branchiopoda) in relation to climate. Journal of Biogeography, vol. 40, no. 8, pp. 1548-1559.

PANARELLI, E.A., GÜNTZEL, A.M. and BORGES, C.N., 2013. How does the Taquari River influence in the cladoceran assemblages in three oxbow lakes? Brazilian Journal of Biology, vol. 73, no. 4, pp. 717-725.

PERBICHE-NEVES, G., FILETO, C., LAÇO-PORTINHO, J., TROGUER, A. and SERAFIM-JÚNIOR, M., 2013. Relations among planktonic rotifers, cyclopoid copepods, and water quality in two Brazilian reservoirs. Latin American Journal of Aquatic Research, vol. 41, no. 1.

PERKINS, D.M., BAILEY, R.A., DOSSENA, M., GAMFELDT, L., REISS, J., TRIMMER, M. and WOODWARD, G., 2015. Higher biodiversity is required to sustain multiple ecosystem processes across temperature regimes. Global change biology, vol. 21, no. 1, pp. 396-406. 
PINEL-ALLOUL, B. and MIMOUNI, E.A., 2013. Are cladoceran diversity and community structure linked to spatial heterogeneity in urban landscapes and pond environments? Hydrobiologia, vol. 715, no. 1, pp. 195-212.

ROSSA, D.C., LANSAC-TÔHA, F.A., BONECKER, C.C. and VELHO, L.F.M., 2001. Abundance of cladocerans in the littoral regions of two environments of the upper Paraná river floodplain, Mato Grosso do Sul, Brazil. Revista Brasileira de Biologia, vol. 61, no. 1, pp. 45-53.

SHURIN, J.B., HAVEL, J.E., LEIBOLD, M.A. and PINELALLOUL, B., 2000. Local and regional zooplankton species richness: a scale-independent test for saturation. Ecology, vol. 81, no. 11, pp. 3062-3073.

SHURIN, J.B., WINDER, M., ADRIAN, R., KELLER, W.B., MATTHEWS, B., PATERSON, A.M. and YAN, N.D., 2010. Environmental stability and lake zooplankton diversity-contrasting effects of chemical and thermal variability. Ecology Letters, vol. 13, no. 4, pp. 453-463.

SILVA, W.M., 2011. Potential use of Cyclopoida (Crustacea, Copepoda) as trophic state indicators in tropical reservoirs. Oecologia Australis, vol. 15, no. 3, pp. 511-521.
SLÁDEČEK, V., 1983. Rotifers as indicators of water quality. Hydrobiologia, vol. 100, no. 1, pp. 169-201.

SWEETMAN, J.N. and RÜHLAND, K.M., 2010. Environmental and spatial factors influencing the distribution of cladocerans in lakes across the central Canadian Arctic treeline region. Journal of Limnology, vol. 69, no. 1, pp. 76-87.

TUNDISI, J.G. and MATSUMURA-TUNDISI, T., 2008. Limnologia. São Paulo: Oficina de Textos, 632 p

VANNI, M.J., 2002. Nutrient cycling by animals in freshwater ecosystems. Annu Rev Ecol Evol Syst., vol. 33, pp. 341-370.

WALSH, J.R., CARPENTER, S.R. and VANDER ZANDEN, M.J., 2016. Invasive species triggers a massive loss of ecosystem services through a trophic cascade. Proceedings of the National Academy of Sciences, vol. 113, no. 15, pp. 4081-4085.

WHITTAKER, R.H., 1972. Evolution and measurement of species diversity. Taxon, pp. 213-251.

WHITTAKER, R.H., 1972. Evolution and measurement of species diversity. Taxon, vol. 21, pp. 213-251 